\title{
POLISH INNOVATIONS IN MANAGEMENT OF IMMIGRATION POLICY
}

\author{
Walery Okulicz-Kozaryn \\ The Institute of Administration of the University of Jan Dlugosz in \\ Czestochowa, Czestochowa, Poland \\ CMESTE \\ JEL Category: J61, 031, 052
}

\begin{abstract}
Research tasks were to analyze the needs of Polish migrant workers and the number of poles that can immigrate from Ukraine, Belarus, Russia, and Kazakhstan. The focus was on the analysis of innovations in immigration policy of Poland. We have performed a study of some scientific sources and practical life examples, and processing of statistical data. We found that Poland needs in the amount of 150000 migrant workers annually. And the Polish card and repatriation provide an influx of poles an average of 20000 people annually. It has two tools for innovations: A Law "About the Polish Card" and a Law "About Repatriation". Innovations of the Polish authorities in immigration policy will have the influx of immigrants to 33 thousand people annually. Unfortunately, it was not enough to compensate for the needs of the labor migrants. As it seems, these innovations attract economically inactive immigrants. It looks right to innovate in the management of immigration policy of Poland. This innovation is directed to the Immigration of the economically active people. It is recommended to change the Law "About the Polish Card" and the Law "About Repatriation" additionally. The main purpose of the recommendations is to reduce administrative barriers for economically active immigrants of Polish origin. A new tool is provided in the form a "Labor Migrant Card". Innovations described in the paper can be useful to the other countries of the European Union.
\end{abstract}

Keywords: Labor migrants, migrant workers, workforce, immigration, labor market, innovation, management of immigration policy, Polish card, repatriation, Law "About the Polish card", Law "About repatriation"

\section{INTRODUCTION}

Do you know why Poland and Europe need migrant workers?

All developed countries of Western Europe faced with a situation where the working age population

The address of the author: Walery Okulicz-Kozaryn 拝=0kvp@yandex.ru declined. None of them could do in this position your own workforce. All countries attracted labor migrants very active. The average annual growth rate of migrants was 500-600 thousand people in 2005 in Western Europe (Yandex.Direkt, Mezhdunarodnaya trudovaya migratsiya, 2015).

It had been demonstrated in (Deyneka \& Bespal'ko, 2013, p. 342): migrant workers have a key role in the grass-roots sectors of the labor market, are not in demand from local workers. The 
importance of migrants is high in "top" segment of the labor market also. Industries which need qualified professionals were described in papers (Deyneka \& Bespal'ko, 2013): managers, scientists, employees of high-tech industries, IT specialists, etc.

There are current demographic trends such, that, if Poland wants to maintain the current pace of development, the poles must attract by 2050 approximately 5 million immigrants (Legalizacja 1 mln ukraincow, 2016). It has about 150,000 labor migrants annually.

In the paper it has the answers to the questions:

1. is there in Poland the problem of attracting labor migrants?

2. what innovations do the Polish authorities to attract labor migrants-poles?

3. What's new can do the Polish authorities in this direction?

The results of the research are applied in the practice of Poland and other countries. They can be useful for countries seeking to raise the pace of development.

\section{BACKGROUND OF THE STUDY}

This will be discussed in the paper these tools to attract a workforce, as the "Polish card", "repatriation" and others.

\subsection{Literature review}

Earlier, European Union countries attracted labor migrants from the countries of North Africa and the Middle East very active. As You can see, lately it was the worsening of behavior problems of labor migrants from these regions (Avstriya: mul'tikul'turalizm mortv, 2016).

According to new publications, people changed the attitude to such migrants [ (Avstriya: mul'tikul'turalizm mortv, 2016), (Polska czeka na potomkow wygnancow, 2016), (Pol'sha otkazyvayetsya prinimat' migrantov po kvotam izza teraktov v Parizhe, 2015), (Pol'sha otkazalas' prinimat' migrantov posle teraktov $v$ Bryussele, 2016)]. And the European Union has a problem: where it is possible to take labor migrants?

Let's go back to the beginning of the paper. Association of entrepreneurs and employers of Poland believes that the need to attract 5 million migrant workers by 2050 (Legalizacja $1 \mathrm{mln}$ ukraincow, 2016).

It has about 150,000 labor migrants annually. This number gives a positive answer to the first question: Yes, Poland has the problem of attracting of labor migrants.

Where to find such a number of skilled and socially adapted labor migrants?

Unlike other countries, Poland has unique resources in this area - the poles living in the East of Poland.

It has two tools to encourage poles to return to Poland:

- a Law "About the Polish card";

- and a Law "About repatriation".

The Polish card was introduced by the Law of 7 September 2007. This is a document confirming a membership to the Polish nation (Sejm, Ustawa o Karcie Polaka z dnia 7 wrzesnia 2007 r. tj. z dnia 30 lipca 2014 r., 2014). Polish consular offices received about 140 thousand requests for the issuance of the Polish card by 15 may 2014 (Pravitel'stvo Pol'shi khochet dat' bol'she prav vladel'tsam Karty polyaka, 2015). This is an average of 20 thousand people annually, who have received the Polish card.

The law "On repatriation" was approved on 9 November 2000 (Sejm, Ustawa o repatriacji z dnia 9 listopada 2000 r. tj. z dnia 4 września 2014 r. (Dziennik Ustaw z 2014 r. poz. 1392), 2014). The Polish Supervisory bodies have monitored the implementation of this Law. It turned out that they had exercised their right of repatriation: in 2007 only 243 people, and in 2012 - only 123, and in 2014 - the number of repatriates dramatically decreased to 64 people (Repatriatsiya v Pol'shu. Polucheniye grazhdanstva, 2015)

In General, about 5 thousand people repatriated to Poland from January 2001 to December 2014 (Szydlo, 2015). On average, 350 poles repatriated to Poland every year.

Thus, we see a serious problem. Poland needs to return the poles in the amount of 150 thousand people annually. And the Polish card and repatriation provide an influx of poles an average of 20 thousand people annually. 
This is another difficulty for Poland. The Polish people go to Germany, Norway and other countries. For example, in 2013, 500 thousand poles left Poland to other countries of the European Union (Iz Pol'shi za god emigrirovalo rekordnoye kolichestvo polyakov, 2014).

In other words, these two tools for attracting of labor migrants (a Law "About the Polish card" and a Law "About repatriation") do not work extremely effectively. Therefore, Poland has the great problem of attracting labor migrants.

\subsection{Methodology}

While the exact methodologies used vary from field to field, the overall process is the same. We used well-documented and powerful methods of analysis. All our methods were economically justified.

Our key research technique was to analyze some scientific sources and practical life examples. In general, we learn approximately 70 scientific sources on an interesting topic. After that, we choose the hot ones for a detailed analysis.

We use the scientific method to search for relationships between the statistics. We welcome alternative and non-traditional positions of researchers.

\section{THE RESULTS OF THE STUDY}

In section 2.1 we got the answer to the question: is there in Poland the problem of attracting labor migrants?

It was shown that Poland has the great problem of attracting labor migrants.

Further, it will be considered the following questions:

- what innovations do the Polish authorities to attract labor migrants-poles?

- What's new can do the Polish authorities in this direction?

\subsection{How many poles can immigrate to Poland?}

For the beginning, let us estimate the ability to compensate for the shortage of human resources through the return of poles living in the East of Poland.
According to official statistics, 2,5 million poles living in the former Soviet Union (Polonia w liczbach, 2015), especially in such countries:

- Belarus - up to 900000 people;

- Ukraine - to 900000 people;

- Russia - up to 300000 people;

- Kazakhstan - up to 50000 people.

This figure (2.5 million) seems low. Association of entrepreneurs and employers of Poland believes that the need to attract 5 million migrant workers by 2050 (Legalizacja $1 \mathrm{mln}$ ukraincow, 2016). And this opportunity looks impossible to compensate for labor shortages by bringing poles from the Eastern countries.

However, in the paper (Okulich-Kazarin, Administrirovaniye immigratsionnoy politiki RP: Skol'ko polyakov "poteryala" statistika?, 2015) it is shown that the official statistics do not provide real numbers. In this paper, it is argued that the real number of poles living to the East from Poland in 7-10 times more than stats.

Let us consider, for example, the real number of poles living in the Asian part of Russia, specifically in Siberia. This is quite important, because, according to the estimates of Polish historians, about 150 thousand Polish exiles passed through Siberia before 1914 (Polyaki v Sibiri, 2015). And, even 135987 poles arrived in Siberia from November 1939 until very beginning of 1941 (Polyaki v Sibiri, 2015).

Further expulsion took place in may-June 1941. About 85000 poles were deported to the Altai and Krasnoyarsk regions, Novosibirsk and other areas of Kazakhstan (Polska czeka na potomkow wygnancow, 2016).

According to official statistics, 36000 poles lived in Siberia at this time. It is evident the difference between official and real figures.

The paradox is that the number of poles living in Ukraine, Belarus, Russia, and Kazakhstan is 7-10 times more than statistically. We can expect 17-25 million poles and their descendants who live today in these countries. This amount is quite sufficient to compensate for the deficit of labor resources in Poland.

This shows that immigration of poles to Poland is a promising direction for the Polish Government. 


\subsection{What innovations do the Polish authorities to bring poles?}

There are two widely discussed topics in Poland: a new Law "About the Polish card" and the new Law "About repatriation". First, we consider what changes the Polish authorities submit to the Law "About the Polish card". Second, we consider what changes the Polish authorities submit to the Law "About repatriation".

Firstly, the deputies of the Polish Sejm want to give more rights to the holders of Polish card. January 14, 2016, parliamentarians of the Polish Sejm supported the Law, which concerns amendments to the Law "About the Polish card". Work will continue with the parliamentary Committee on liaison with poles abroad ( $\mathrm{V}$ seyme khotyat dat' bol'she prav vladel'tsam karty polyak, 2016):

- It provides that owners of the Polish card will receive assistance in settling their life in Poland. They will have almost the same rights as Polish citizens in emergency situations (as, for example, the conflict in the Donbas).

- It is suggested that the persons with the Polish card could receive a permit to stay in Poland for free. And after one year of residence - they can receive Polish citizenship automatically.

- It is also expected that the Polish government may pay for them Polish language courses and training partly.

- The deputies want to exempt Holders of the Polish card from consular fees for visas and other applications.

- One of the amendments provides a financial assistance for living in Poland cardholders in the amount of 5400 euros for each family member.

Secondly, the ruling party of Poland is preparing a new draft of Law "About repatriation". I want to clarify that the essence of this Law is "the moral obligation of the state" to facilitate the repatriation of the Polish people. I consider this Law from the point of view of human resources and immigration policy.

The project contains:

- it has provisions dealing with principles of professional activity of repatriates;

- it provides assistance by creating jobs, training of repatriates and also refund part of the cost for training;

- it has also provided funds to cover expenses during the first three years after arrival in Poland.

The new draft of Law provides for two options of repatriation:

- The first option is valid today - it is an invitation to local government.

- The second option involves the assistance of the official Warsaw.

The project involved the expansion of the number of persons entitled to repatriation.

It is obvious that the Polish authorities are preparing innovations in the Legislation. These innovations are very important as the fulfillment of a moral obligation, on the one hand. On the other hand, these innovations in migration policy are useful for attracting labor migrants.

Thus, we have already found the answer to the second question: what innovations make the Polish authorities to attract labor migrants?

This follows from the analysis of the documents that the Polish authorities are preparing several innovations to the two Laws facilitating the immigration of poles from other countries. These amendments consist of administrative support and financial assistance. This is provided by the expansion of the number of persons who can live and work in Poland.

As it seems to me, these innovations attract economically inactive immigrants.

Previously the countries of the European Union had made that mistake. They attracted migrant workers from North Africa and the Middle East through large financial assistance. As You can see, lately it is the worsening of behavior problems of labor migrants from these regions [ (Avstriya: mul'tikul'turalizm mortv, 2016), (Khuligany sozhgli v Parizhe 804 avtomobilya za odnu noch', 2016)]. This situation could be repeated in Poland.

It looks right to innovate in the management of immigration policy. It is thought that it will be useful to introduce a new principle in immigration policy of Poland. This innovation is directed to the Immigration of the economically active people.

And now we go to a search of the answer to the third question: what's new can do the Polish 
authorities in this direction? In other words, what recommendations can we give to Polish authorities for attracting more labor migrantspoles?

\subsection{What's new can do the Polish authorities for bringing poles else}

Let's return once more to the statistics.

1. Thanks to the amendments to the Law "About the Polish card", in the next few years, about 100 thousand people of Polish origin to enter Poland from Ukraine, Belarus, Russia and Kazakhstan (Jest projekt nowelizacji ustawy o Karcie Polaka, 2016).

If we divide 100,000 poles in 3-5 years, we will get an influx of immigrants 20-33 thousands of people annually.

2. Additionally, the new Law "About repatriation" can take 10000 people (Yandex.Direkt, Bedzie nowa ustawa o repatriacji, 2016). If we divide 10000 poles in 3-5 years, we will get an influx of immigrants 2,0-3,3 thousands of people annually.

3. As a result, amendments to two laws provide for the return of only 22 to 33 thousand of poles. It has about $20 \%$ of the demand for migrant workers.

What can be done to increase the number of poles who return to Poland?

It can be recommended to the Polish authorities. All actions can be divided into three groups:

1. the removal of administrative barriers at the realization of the Law "About the Polish card";

2. the expansion of the scope of the Law "About repatriation";

3. a using of innovations in the form of a "Labour migrant card".

First. Administrative barriers at the Law "About the Polish card".

Unfortunately, the process of obtaining the "Polish card" has several administrative barriers:

- the "Polish card" is limiting opportunities for an immigration. It does not give the right to the visa-free crossing of the Polish border or a settlement in Poland (Ustawa o Karcie Polaka, 2007, article 7). Cross the border and stay in Poland for the holders of the "Polish card" is possible by obtaining a national visa type " $\mathrm{D}$ " (Ustawa o Karcie Polaka, 2007, article 7). It takes time getting "D" visa.

- it is very important to have documents that one parent or grandfather/grandmother or great grandfather and great grandmother were of Polish nationality or had Polish citizenship (Ustawa o Karcie Polaka, 2007, p.1.3, article 2).

- the "Polish card" can be obtained by a person who can "prove their connection with the nation". This can be a basic knowledge of Polish language, knowledge and cultivation of Polish traditions (Ustawa o Karcie Polaka, 2007, p.1.1, article 2).

- is there a need to go to the Consul of the Republic of Poland to submit "a written Declaration of belonging to the Polish Nation" (Ustawa o Karcie Polaka, 2007, p.1.2, article 2). This rule has a serious limitation due to the large size of Russia and Kazakhstan.

- the majority of the capable poles living in Russia and Kazakhstan have spouses and children. The law "Polish card" has no rules governing relations between poles and spouses. And this fact also limits the possibility of immigration of poles.

Analysis of legal documents and private information helps to adjust the Law "About the Polish card". Such innovations are recommended:

- to soften the attitude of the poles living in the former Soviet Union - replace "proving" to softer terms and procedures;

- to allow the descendants of exiled poles to use supporting documents up to 10 generations;

- to revise the rules relating to the knowledge of the Polish language and traditions;

- to provide various possibilities to apply for the "Polish card" without a personal visit to the Consulate of the Republic of Poland;

- to introduce a legal provision for obtaining a "card of the spouse of the pole";

- to exclude the possibility of a refusal to issue the "Polish card" for subjective reasons.

Second. The expansion of the scope of the Law "About repatriation".

Unfortunately, the repatriation process has a number of administrative barriers also:

it is to have documents that one parent or grandfather/grandmother or great grandfather and great grandmother were of Polish nationality or 
had Polish citizenship.

- it is the requirement for local authorities to give housing to immigrants. Local authorities unable to provide housing for this category of descendants of poles:

- this is the high cost of translated and notarized documents.

- the problem is that in the Law "About repatriation" is not specified the processing time.

Analysis of legal documents and private information helps to adjust the Law "About About repatriation" (Ustawa o repatriacji, 2000; (OkulichKazarin, The administration of migration policy of Poland: three important changes in the Law "About repatriation", 2015). Such innovations are recommended:

- to record p.1 of article 5.1 in the next edition "at least one parent and a grandparent, also great-grandmother or great-grandfather to 7 generations, were of Polish nationality or had Polish citizenship".

- to repeal p.2 and p.3 of article 5.

- to repeal article 11, article 12, article 12A.

- to record p.4 of article 5 in the next edition of "Decisions on the issues referred to in paragraph 1 , taken by the Consul within 1 (one) week from the date of receipt of the documents. The Consul shall issue to the Person of Polish descent "Polish card" within 1 (one) month from the date of the decision on the matters referred to in paragraph 1".

- this is an opportunity for immigrants to buy their own housing themselves. This will stimulate the arrival of economically active poles.

Finally. Innovations in the form of a "Labour migrant card".

Analysis of legal documents and private information showed the main barrier to the return poles. This barrier is the lack of documentation about the Polish origin.

This barrier is contrary to "right of blood" was adopted in Poland. He also does not correspond to reality. Ethnic poles residing "in the Asian part of the former USSR", as a rule, do not have documents confirming Polish citizenship or Polish nationality.
Such innovation is recommended for ethnic poles who do not have documents confirming Polish citizenship or Polish nationality. It is useful to take the "Labour migrant card" for poles who do not have documents confirming Polish citizenship or Polish nationality.

The "Labour migrant card" can be issued to a person who is highly qualified, considers himself a pole and/or has a Polish surname. This "card" should give the right:

- for a visa "D" for pole and members of his family;

- the right to work without additional permission.

\section{CONCLUSIONS}

These were given answers to the questions in our study:

1. is there in Poland the problem of attracting labor migrants?

2. what innovations do the Polish authorities to attract labor migrants-poles?

3. what's new can do the Polish authorities in this direction?

In section 2.1 it is shown, that Poland has the great problem of attracting labor migrants. Poland needs to return the poles in the amount of 150 thousand people annually. And the Polish card and repatriation provide an influx of poles an average of 20 thousand people annually only.

In section 3.1. it is shown that this can be expected 17-25 million poles and their descendants who live in Ukraine, Belarus, Russia and Kazakhstan today. This amount is quite enough to compensate for the deficit of labor resources in Poland.

And the task of the authorities of Poland is to create conditions for the return of poles from these countries.

In section 3.2 it was performed the analysis of innovations in the management of the immigration policy of the Republic of Poland. The Polish authorities revise the Law "About the Polish card" and the Law "About repatriation".

These innovations aimed to encourage the arrival of poles from Ukraine, Belarus, Russia and Kazakhstan. They provide material assistance to the poles, with the documents belonging to the Polish nation.

It's proven statistically that the proposed 
innovation is not sufficient to compensate for the deficiency of labor resources.

As it seems to me, these innovations attract economically inactive immigrants.

It looks right to innovate in the management of immigration policy of Poland. This innovation is directed to the Immigration of the economically active people.

In section 3.3 recommendations given to empower the return to Poland of a larger number of poles from Ukraine, Belarus, Russia and Kazakhstan. And these recommendations are useful to attract to Poland the economically active immigrants.
The main innovations are divided into three groups:

1. changes in the Law "About the Polish card".

2. changes in the Law "About repatriation".

3. the initiation of the adoption of the Law "About Labour migrant card".

The purpose of further research is the analysis of the conditions for the Law "About Labour migrant card".

Innovations that are described in sections 3.2 and 3.3 can be useful for other countries of the European Union.

\section{WORKS CITED}

Deyneka, A., \& Bespal'ko, V. (2013). Upravleniye chelovecheskimi resursami. Moscow: Dashkov i K.

Okulich-Kazarin, V. (2015). Administrirovaniye immigratsionnoy politiki RP: Skol'ko polyakov "poteryala" statistika? Innovatsionnaya ekonomika: Perspektivy razvitiya i sovershenstvovaniya - Nauchnoprakticheskiy zhurnal (4), 17-20.

Okulich-Kazarin, V. (2015). The administration of migration policy of Poland: three important changes in the Law "About repatriation". 3rd International Conference "Modern jurisprudence: legal thought and enforcement practice", (pp. 56-58). Sheffield, Great Britain.

Sejm. (2014, July 30). Ustawa o Karcie Polaka z dnia 7 wrzesnia 2007 r. tj. z dnia 30 lipca 2014 r. Retrieved from isap.sejm.gov.pl: http://isap.sejm.gov.pl/Download;jsessionid=1DDD302D03A269360D659251F2992781 ?id=W DU20071801280\&type $=1$

Sejm. (2014, Sep 04). Ustawa o repatriacji z dnia 9 listopada 2000 r. tj. z dnia 4 września 2014 r. (Dziennik Ustaw z 2014 r. poz. 1392). Retrieved from isap.sej.gov.pl: http://isap.sejm.gov.pl/Download?id=WDU20140001392\&type=1

Szydlo, B. (2015, Oct 17). Nowa ustawa repatriacyjna w ciągu pierwszych 100 dni nowego rządu/. Retrieved from onet.wiadomosci: http://wiadomosci.onet.pl/kraj/szydlo-nowa-ustawarepatriacyjna-w-ciagu-pierwszych-100-dni-nowego-rzadu/yerwvy

Yandex.Direkt. (2014, Feb 12). Iz Pol'shi za god emigrirovalo rekordnoye kolichestvo polyakov. Retrieved from unian.net: http://www.unian.net/world/883208-iz-polshi-za-god-emigrirovalorekordnoe-kolichestvo-polyakov.html

Yandex.Direkt. (2015, Dec 18). Mezhdunarodnaya trudovaya migratsiya. Retrieved from grandars.ru: http://www.grandars.ru/student/mirovaya-ekonomika/m-trudovaya-migraciya.html

Yandex.Direkt. (2015, Nov 14). Pol'sha otkazyvayetsya prinimat' migrantov po kvotam iz-za teraktov $v$ Parizhe.

Retrieved from

gazeta.ru: http://www.gazeta.ru/social/news/2015/11/14/n_7887425.shtml

Yandex.Direkt. (2015, Oct 12). Polyaki v Sibiri. Retrieved from Biblioteka Sibirskogo Krayevedeniya: http://bsk.nios.ru/enciklodediya/polyaki-v-sibiri

Yandex.Direkt. (2015, Nov 26). Pravitel'stvo Pol'shi khochet dat' bol'she prav vladel'tsam Karty polyaka. Retrieved from news.tut.by: http://news.tut.by/world/474503.html

Yandex.Direkt. (2015, July 12). Repatriatsiya v Pol'shu. Polucheniye grazhdanstva. Retrieved from typicalpoland.com: http://typicalpoland.com/immigration/repatriation/ 
Yandex.Direkt. (2016, Jan 26). Avstriya: mul'tikul'turalizm mortv. Retrieved from stoletie.ru: http://www.stoletie.ru/zarubejie/avstrija_multikulturalizm_mertv_484.htm

Yandex.Direkt. (2016, Jan 26). Bedzie nowa ustawa o repatriacji. Retrieved from gosc.pl: http://gosc.pl/doc/2943735.Bedzie-nowa-ustawa-o-repatriacji

Yandex.Direkt. (2016, Mar 26). Jest projekt nowelizacji ustawy o Karcie Polaka. Retrieved from znadniemna.pl: http://znadniemna.pl/13706/jest-projekt-nowelizacji-ustawy-o-karcie-polaka/

Yandex.Direkt. (2016, Jan 02). Khuligany sozhgli v Parizhe 804 avtomobilya za odnu noch'. Retrieved from newstube.ru: http://www.newstube.ru/media/huligany-sozhgli-v-parizhe-804-avtomobilyaza-odnu-noch

Yandex.Direkt. (2016, Jan 26). Legalizacja $1 \mathrm{~m} / \mathrm{n}$ ukraincow. Retrieved from zpp.net.pl: http://zpp.net.pl/aktualnosci/run,legalizacja-1-mln-ukraincow,page, 1, article,1083.html?

Yandex.Direkt. (2016, Mar 244). Pol'sha otkazalas' prinimat' migrantov posle teraktov $v$ Bryussele. Retrieved from gazeta.ru: http://www.gazeta.ru/social/news/2016/03/24/n_8410661.shtml

Yandex.Direkt. (2016, Jan 26). Polska czeka na potomkow wygnancow. Retrieved from kurierwilenski.lt: http://kurierwilenski.It/2016/01/26/ustawa-o-repatriacji-polska-czeka-na-potomkowwygnancow/

Yandex.Direkt. (2016, Jan 15). V seyme khotyat dat' bol'she prav vladel'tsam karty polyak. Retrieved from krynica.info: http://krynica.info/2016/01/15/v-sejjme-khotyat-dat-bolshe-prav-vladelcamkart-polyaka/

Yandex.Direkt. (2015, Oct 23). Polonia w liczbach. Retrieved from bsk.nios.ru: http://wspolnotapolska.org.pl/polonia_w_liczbach.html

Received for publication: $\quad 01.04 .2016$

Revision received: $\quad 28.08 .2016$

Accepted for publication: $\quad 12.12 .2016$

\section{How to cite this article?}

Style - APA Sixth Edition:

Okulicz-Kozaryn, W. (2017, Jan 15). Polish innovations in management of immigration policy. (Z. Cekerevac, Ed.) MEST Journal, 5(1), 70-77. doi:10.12709/mest.05.05.01.09

Style - Chicago Sixteenth Edition:

Okulicz-Kozaryn, Walery. "Polish innovations in management of immigration policy." Edited by Zoran Cekerevac. MEST Journal (MESTE) 5, no. 1 (Jan 2017): 70-77. doi:10.12709/mest.05.05.01.09

Style - GOST Name Sort:

Okulicz-Kozaryn Walery Polish innovations in management of immigration policy [Journal] // MEST Journal / ed. Cekerevac Zoran. - Belgrade - Toronto : MESTE, Jan 15, 2017. - 1 : Vol. 5. - pp. 70-77.

Style - Harvard Anglia:

Okulicz-Kozaryn, W., 2017. Polish innovations in management of immigration policy. MEST Journal, 15 Jan, 5(1), pp. 70-77.

Style - ISO 690 Numerical Reference:

Polish innovations in management of immigration policy. Okulicz-Kozaryn, Walery. [ed.] Zoran

Cekerevac. 1, Belgrade - Toronto : MESTE, Jan 15, 2017, MEST Journal, Vol. 5, pp. 70-77. 